\title{
EFFECT OF THE WATER EXTRACT OF THE FOUR O'CLOCK HERB (MIRABILIS JALAPA L.) ON THE HEALING OF OPEN WOUNDS IN RATS
}

\author{
PUSPITA PUSPASARI, FADLINA CHANY SAPUTRI* \\ Department of Pharmacology, Faculty of Pharmacy, Universitas Indonesia, Depok, 16424, Indonesia. \\ Email: fadlina.chany@farmasi.ui.ac.id
}

Received: 08 May 2018, Revised: 23 September 2018, Accepted: 22 November 2018

\section{ABSTRACT}

Objective: This study aimed to analyze the effect on wound healing following treatment with a water extract of Mirabilis jalapa L. by investigating wound contraction and the associated histopathological changes in rat skin.

Methods: Male Sprague-Dawley rats were divided into five groups, namely negative control, positive control (povidone-iodine), dose 1, dose 2, and dose 3. A 20-×10-mm rectangular wound area was created for the test. In dose 1, 2, and 3 groups, the corresponding dose variation of a 0.5 -mL M. jalapa L. water extract (dose 1: $5 \% \mathrm{v} / \mathrm{v}, \approx 243.1 \mathrm{mg} / \mathrm{kg}$ body weight BW; dose 2: $10 \% \mathrm{v} / \mathrm{v}, \approx 486.2 \mathrm{mg} / \mathrm{kg} \mathrm{BW;} \mathrm{and} \mathrm{dose} \mathrm{3:} 20 \% \mathrm{v} / \mathrm{v}, \approx 972.4 \mathrm{mg} / \mathrm{kg} \mathrm{BW}$ ) was topically applied for 14 days on open wounds of rats. Widespread wound contractions were measured on days $1,3,5,7,9,11$, and 13 , and histopathological changes in the skin were observed on day 15 using hematoxylin and eosin staining.

Results: The M. jalapa L. water extract accelerated wound healing. The optimal dose was found to be $20 \% \mathrm{v} / \mathrm{v}(\approx 972.4 \mathrm{mg} / \mathrm{kg} \mathrm{BW}$ ).

Conclusion: M. jalapa L. extracts are potential healing agents for open wounds.

Keywords: Mirabilis jalapa L., Open wound, Povidone-iodine, Histopathology, Wound healing.

(C) 2018 The Authors. Published by Innovare Academic Sciences Pvt Ltd. This is an open access article under the CC BY license (http://creativecommons. org/licenses/by/4. 0/) DOI: http://dx.doi.org/10.22159/ijap.2018.v10s1.33

\section{INTRODUCTION}

Wounds are tissue injuries that interfere with normal cellular processes. They involve damage to the unity of the body tissues, usually accompanied by the loss of tissue substance. Open wounds involve damage to the skin or mucous membranes and a possibility of bleeding accompanied by tissue damage and a risk of infection [1]. Wounds are classified as acute or chronic based on their severity, and both types are at the risk of infection. Acute wounds are fast healing, for example, stitched surgical lesions, trauma wounds, and blisters [1]. The most commonly used antiseptic drug for wounds is $10 \%$ povidone-iodine, which contains 1\% available iodine that can kill bacteria in $1 \mathrm{~min}$ and spores within 15 min. However, excessive iodine use may inhibit the wound granulation process. Side effects occur when it is used on a widespread skin surface (e.g., wounds using $>0.9 \mathrm{~mL} /$ per day) because iodine stimulates and increases serum levels resulting in acidosis, neutropenia, and hypothyroidism [2]

Based on the high prevalence ofinjuries and side effects caused by existing medicines, the development of an alternative agent for wound healing is necessary. A potential candidate is the four o'clock herb Mirabilis jalapa L., an ornamental garden plant. The infusion and decoction of $M$. jalapa L. have been traditionally employed as an anti-inflammatory and pain medication in Brazil. In vitro studies have revealed that the flowers primarily contain flavonoids and anthocyanins [3]. In addition, the antibacterial activity of an $M$. jalapa L. extract was investigated using bioautography with Staphylococcus aureus and Escherichia coli as the test organisms [4-6].

M. jalapa L. contains $\beta$-sitosterol-D-glucoside. This natural estrogenic steroid maintains the moisture in the wound area, promoting cell growth. In the inflammatory phase, $\beta$-sitosterol limits the amount of prostacyclin, thereby accelerating the inflammatory phase. Flavonoids limit the amount of free radicals, preventing excessive tissue damage in the inflammatory phase [7-9]. The purpose of this study was to analyze the effects of an $M$. jalapa L. extract on the acceleration of open wound healing. This was assessed based on the percentage of widespread wound contraction and the histopathological changes observed in the skin of rats with open sores to determine the optimal extract dose.

\section{METHODS}

\section{Extract preparation}

Herbal extracts consisting of flowers, leaves, and tubers of M. jalapa L. were supplied by Research Institute for Spices and Medicinal Plants (BALITTRO), Cimanggu, Bogor, West Java. Extraction was performed by water solvent using the maceration method over 7 days. Subsequently, the solvent was removed through evaporation, and a thick extract remained.

Phytochemical screening and determination of total flavonoid content

Phytochemical screening was performed on the extracts to identify the presence of flavonoid, tannin, alkaloid, saponin, phenolic, triterpenoid, steroid, and glycoside compounds. The total flavonoid content was also assessed to determine the flavonoid levels in the extracts that were supposedly responsible for the biological activity to be tested.

\section{Testing materials manufacturing}

The herbal extracts of $M$. jalapa $\mathrm{L}$. were sterilized in an autoclave at $121^{\circ} \mathrm{C}$ for $15 \mathrm{~min}$. Subsequently, they were dissolved in water at room temperature $\left(25^{\circ} \mathrm{C}-27^{\circ} \mathrm{C}\right)$ to achieve the required dosage as calculated.

\section{Preparing trial animals}

Male Sprague-Dawley male rats were obtained from the Faculty of Agriculture, Bogor Agricultural University, Indonesia. The animals were given food and water ad libitum for 14 days to acclimatize to the new environment. During acclimatization, the general state and any weight loss of the rats were observed to select only healthy rats for the study use. This study was approved by the Ethics Committee of Health 
Research, Faculty of Medicine, Universitas Indonesia (No. 504/UN2.F1/ ETIK/2015).

\section{Determination of extract dose}

Preliminary experiments were performed to determine the dose and treatment duration of the M. jalapa L. water extract required to affect wound healing. Four rats were used. Two cuts on the upper and lower rumps were made at $3-\mathrm{cm}$ intervals. The eight wounds were randomly divided into four groups. Each group was treated as per Table 1.

Following the injury, the extract was applied daily to the injury site. All wounds were covered with sterile gauze. Daily observations were performed until the wound had healed. In the preliminary trial, the best result was obtained from dose 3 , with wound closure on day 14 . This optimum dose was used as the middle dose in our study.

\section{Open wound procedure}

The rats were shaved in the upper back area before anesthetization using ether. The upper back and surrounding areas were cleaned with 70\% alcohol. Subsequently, a rectangular 20-×10-×2-mm (length $\times$ width $\times$ depth) wound was made.

\section{Trial implementation}

A total of 15 male rats received two wound treatments, each on the upper and lower back separated by $3-\mathrm{cm}$ intervals. Thus, 30 sets of treatment data were obtained from the 15 rats. The 30 wound sites were randomly divided into five treatment groups (Table 2) of six wounds each. A topical dropping technique was used to administer 10 standard drops $(0.5 \mathrm{~mL})$ daily at the same time for 14 days.

\section{Wound observation}

Widespread vertical and horizontal wound measurements were taken on days $1,3,5,7,9,11$, and 13 . The average area of measurement was used for assessment. The wound was considered rectangular, and the wound area was calculated as follows: Widespread=length $\times$ width. The percentage of wound contraction was calculated by dividing (L1 - L2) with L1, then times $100 \%$, where L1 is the initial wound area, and L2 is the wound area on the day of observation.

\section{Histopathological observation}

For histopathology, the normal histological features of the skin were compared to determine the extent of wound tissue repair all rats were sacrificed for their skin on day 15 by neck dislocation. The internal organs were removed followed by skin removal. The cut skin sample was soaked in a $10 \%$ formalin buffer solution followed by ethanol dehydration and mounting in a paraffin block. Subsequently, 5- $\mu \mathrm{m}$ thick samples were cut using a Spencer 1010-SMT-006 microtome (New Delhi, India) and stained with hematoxylin and eosin. Fibroblasts, collagen, angiogenesis, neutrophils, reepithelization, and sebaceous glands were observed under a Leica DM 750 light microscope (Leica Microsystems, Heerbrugg, Switzerland).

\section{Data processing}

The percentage of data obtained for wound contraction were tested for normality and homogeneity. Normal and homogeneous data were analyzed using one-way analysis of variance. If the data obtained were not normal or homogeneous, non-parametric analysis was performed by direct data comparison between treatment groups to determine whether the data were significantly different.

\section{RESULTS}

Phytochemical screening and determination of total flavonoid content

The M. jalapa L. extract screened positive for flavonoids (Table 3). Further testing revealed a $0.87 \%$ flavonoid composition.

\section{Test results of wound healing activity}

The percentage of wound contraction was calculated on days 1, 3, 5, 7, 9, 11, and 13 (Table 4).

\section{Histopathological analysis}

The results of the histopathological analysis of rat skin at day 15 are presented in Table 5 and Fig. 1.

\section{DISCUSSION}

Previous research has established that $\beta$-sitosterol-D-glucoside is a natural steroid contained in extracts of M. jalapa L. $[5,6]$. However, the results of phytochemical screening in our study were not positive for steroids. This could perhaps be because our extract comprised flowers, leaves, and tubers of M. jalapa L., whereas the extracts mentioned in the previous studies could have contained different components or concentrations of M. jalapa L. Furthermore, our extract was autoclaved at $121^{\circ} \mathrm{C}$ before use, and this could have possibly altered the stability of any steroid phytotoxins that were present [10-13].

Based on Table 4, the highest mean wound reduction percentage at day 13 was by dose $3(97.42 \%)$ followed by that by dose 1 , the positive

Table 1: Preliminary trial treatment groups

\begin{tabular}{|c|c|c|}
\hline Group & Wound size $\left(2 \mathrm{~cm}^{2}\right)$ & Treatment \\
\hline Positive control & Two wounds & Positive control, rats were wounded and given $10 \%$ povidone-iodine \\
\hline Dose 1 & Two wounds & Rats wounded and given $0.1 \% \mathrm{v} / \mathrm{v}(\approx 4.86 \mathrm{mg} / \mathrm{kg} \mathrm{BW})$ M. jalapa $\mathrm{L}$. water extract \\
\hline Dose 2 & Two wounds & Rats were wounded and given $1 \% \mathrm{v} / \mathrm{v}(\approx 48.6 \mathrm{mg} / \mathrm{kg} \mathrm{BW})$ M. jalapa L. water extract \\
\hline Dose 3 & Two wounds & Rats were wounded and given $10 \% \mathrm{v} / \mathrm{v}(\approx 486.0 \mathrm{mg} / \mathrm{kg} \mathrm{BW})$ M. jalapa L. water extract \\
\hline
\end{tabular}

M. jalapa: Mirabilis jalapa, BW: Body weight

Table 2: Animal testing groups used

\begin{tabular}{|c|c|}
\hline Treatment group & Type of treatment \\
\hline Negative control & $\begin{array}{l}\text { The rats were injured, and the wound was treated with } 10 \text { drops }(0.5 \mathrm{~mL}) \text { of solvent daily at the same time for } \\
14 \text { days. }\end{array}$ \\
\hline Positive control & $\begin{array}{l}\text { The rats were injured, and the wound was treated with drops }(0.5 \mathrm{~mL}) \text { of } 10 \% \text { povidone-iodine solution daily at the } \\
\text { same time for } 14 \text { days. }\end{array}$ \\
\hline Dose 1 & $\begin{array}{l}\text { The rats were injured, and the wound was treated with } 10 \text { drops }(0.5 \mathrm{~mL}) \text { of the } M . \text { jalapa } \mathrm{L} \text {. extract at dose } 1 \\
(5 \% \mathrm{v} / \mathrm{v} \text { extract, } \approx 243.1 \mathrm{mg} / \mathrm{kg} \mathrm{BW}) \text { daily for } 14 \text { days. }\end{array}$ \\
\hline Dose 2 & $\begin{array}{l}\text { The rats were injured, and the wound was treated with } 10 \text { drops }(0.5 \mathrm{~mL}) \text { of the } M . \text { jalapa } \mathrm{L} \text {. extract at dose } 2 \\
(10 \% \mathrm{v} / \mathrm{v}, \approx 486.2 \mathrm{mg} / \mathrm{kg} \mathrm{BW}) \text { daily for } 14 \text { days. }\end{array}$ \\
\hline Dose 3 & $\begin{array}{l}\text { The rats were injured, and the wound was treated with } 10 \text { drops }(0.5 \mathrm{~mL}) \text { of the } M \text {. jalapa L. extract at dose } 3 \\
(20 \% \mathrm{v} / \mathrm{v}, \approx 972.4 \mathrm{mg} / \mathrm{kg} \mathrm{BW}) \text { daily for } 14 \text { days. }\end{array}$ \\
\hline
\end{tabular}



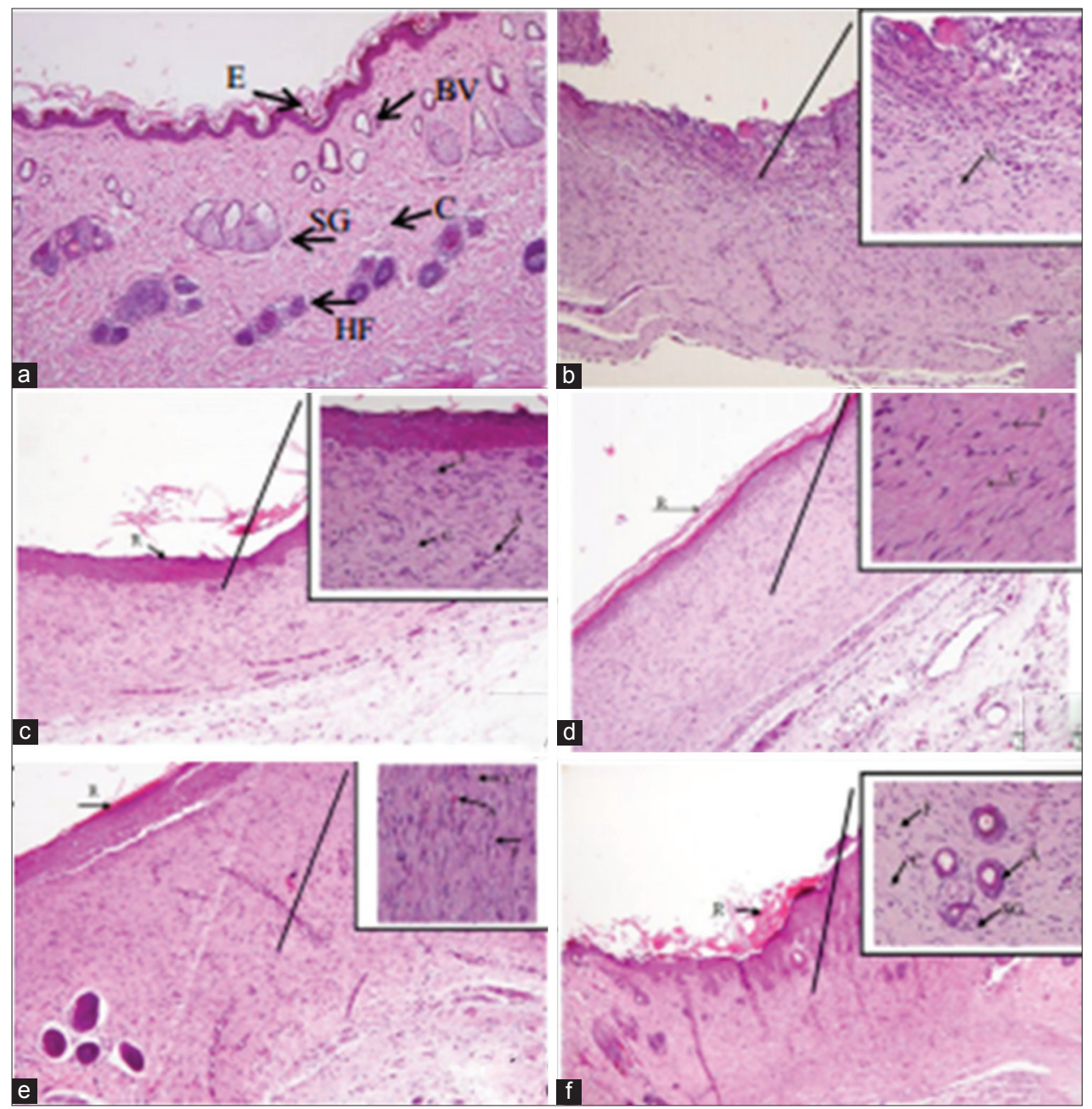

Fig. 1: Histopathologic observations of prepared rat skin stained with hematoxylin and eosin and examined under 100× magnification on day 15. (a) Normal control, (b) positive control $=0.5-\mathrm{mL} 10 \% \mathrm{v} / \mathrm{v}$ povidone-iodine, $(\mathrm{c})$ negative control $=0.5-\mathrm{mL}$ water, $(\mathrm{d}) \mathrm{dose}$ $1=0.5-\mathrm{mL} 5 \%$ Mirabilis jalapa L. water extract, (e) dose $2=0.5-\mathrm{mL} 10 \% \mathrm{v} / \mathrm{v}$ M. jalapa L. water extract, (f) dose $3=0.5-\mathrm{mL} 20 \% \mathrm{v} / \mathrm{v}$ M. jalapa $\mathrm{L}$. water extract. $\mathrm{F}=$ Fibroblasts, $\mathrm{C}=$ collagen, $\mathrm{R}=$ Reepithelization, $\mathrm{N}=$ neutrophil, $\mathrm{HF}=$ hair follicle formation, $\mathrm{BV}=\mathrm{blood}$ vessels, $\mathrm{A}=$ angiogenesis, $\mathrm{SG}=$ sebaceous glands.

\section{Table 3: Results of four o'clock herbal extract content screening}

\begin{tabular}{ll}
\hline Class of compounds & Results \\
\hline Flavonoids & + \\
Tannins & + \\
Alkaloids & + \\
Saponins & + \\
Phenolics & + \\
Triterpenoids & - \\
Steroids & - \\
Glycosides & + \\
\hline
\end{tabular}

control, dose 2, and the negative control. This indicates that dose 3 caused the fastest wound contraction from the three M. jalapa L. extracts tested.

The statistical test results revealed a significant difference between the results of the negative control and those of the positive control and dose 3 on day $1(\mathrm{p}<0.05)$, suggesting that a wound-healing effect was already being exerted as early as the $1^{\text {st }}$ day of treatment with dose 3 . Meanwhile, the other dose groups demonstrated significantly different results from those of the negative control on day 3 .

The open wound healing activity that was observed following treatment with the M. jalapa L. extract could have been caused by its high content of flavonoid compounds. Flavonoids have been known to limit the amount of free radicals that prevent excessive tissue damage in the inflammatory phase $[7,9]$. Clinically, inflammation is the second phase of the healing process and is characterized by erythema, swelling, and temperature increases that are often associated with pain. Furthermore, the antibacterial activity of the M. jalapa L. extract enhances the acceleration of wound healing [14]. This could be particularly useful in treating open wounds, where infection is highly likely and would inhibit the healing process [15].

Based on the histopathological features (Table 5), we concluded that the anti-inflammatory effect of the M. jalapa L. water extract was observed at all doses, that is, neutrophils as an inflammatory indicator were not observed. Moreover, indicators of angiogenesis and sebaceous glands were close to normal in the M. jalapa L. water extract groups compared with those in the control groups, indicating accelerated wound healing.

A limitation of our study is that only one extract batch was tested. Further studies should investigate multiple extract batches to determine variation in extract composition and establish the optimal composition parameters required for accelerated wound healing.

\section{CONCLUSION}

Based on our results, it can be concluded that M. jalapa L. extract has the potential to aid wound healing as demonstrated by widespread 
Table 4: Calculation results of percentage contraction of the wound area

\begin{tabular}{|c|c|c|c|c|c|c|c|}
\hline \multirow[t]{2}{*}{ Treatment group } & \multicolumn{7}{|c|}{ Average percentage of widespread wound contraction (\%) } \\
\hline & Day 1 & Day 3 & Day 5 & Day 7 & Day 9 & Day 11 & Day 13 \\
\hline Positive control & $8.07^{*}$ & $23.14^{*}$ & $38.28 *$ & $53.21^{*}$ & $66.92 *$ & $82.07^{*}$ & $95.57^{*}$ \\
\hline Dose $1(5 \% \mathrm{v} / \mathrm{v})$ & 4.21 & $15.21^{*}$ & $36.28 *$ & $51.35^{*}$ & $62.07 *$ & $82.07^{*}$ & $97.27 *$ \\
\hline Dose $2(10 \% \mathrm{v} / \mathrm{v})$ & $8.33^{*}$ & $23.50^{*}$ & $35.83^{*}$ & $56.58^{*}$ & $69.83^{*}$ & $81.50^{*}$ & 95.33* \\
\hline Dose $3(20 \% \mathrm{v} / \mathrm{v})$ & $6.07^{*}$ & $20.00 *$ & $33.92 *$ & $52.57^{*}$ & $66.28 *$ & $82.00 *$ & $97.42 *$ \\
\hline
\end{tabular}

The application of the M. jalapa L. water extract to open wounds was tested at three different doses. *Significantly different compared to negative control ( $\mathrm{p}<0.05$ )

Table 5: Comparison of significant histopathological differences between treatment groups on day 15

\begin{tabular}{|c|c|c|c|c|c|c|c|c|c|}
\hline \multirow[t]{2}{*}{ Group } & \multirow[t]{2}{*}{ Data } & \multicolumn{6}{|l|}{ Indicator } & \multirow[t]{2}{*}{ Scoring } & \multirow[t]{2}{*}{ Average scoring } \\
\hline & & Reepithelization & Fibroblasts & Collagen & Angiogenesis & Sebaceous Glands & Neutrophils & & \\
\hline Normal & 1 & 1 & 1 & 1 & 1 & 1 & 0 & 5 & 5.0 \\
\hline \multirow{2}{*}{ Positive control } & 2 & 1 & 1 & 1 & 1 & 1 & 0 & 5 & \\
\hline & 3 & 1 & 1 & 1 & 1 & 0 & 0 & 4 & 5.0 \\
\hline \multirow[t]{3}{*}{ Negative control } & 1 & 1 & 1 & 1 & 1 & 0 & 1 & 5 & \\
\hline & 2 & 1 & 0 & 0 & 0 & 0 & 1 & 2 & \\
\hline & 3 & 1 & 0 & 0 & 0 & 0 & 1 & 2 & 3.0 \\
\hline \multirow[t]{3}{*}{ Dose 1} & 1 & 1 & 1 & 1 & 0 & 0 & 0 & 3 & \\
\hline & 2 & 1 & 1 & 1 & 0 & 0 & 0 & 3 & \\
\hline & 3 & 1 & 1 & 1 & 1 & 0 & 0 & 4 & 3.333 \\
\hline \multirow[t]{3}{*}{ Dose 2} & 1 & 1 & 1 & 1 & 1 & 0 & 0 & 4 & \\
\hline & 2 & 1 & 1 & 1 & 1 & 0 & 0 & 4 & \\
\hline & 3 & 1 & 1 & 1 & 1 & 1 & 0 & 5 & 4.333 \\
\hline \multirow[t]{2}{*}{ Dose 3} & 1 & 1 & 1 & 1 & 1 & 1 & 0 & 5 & \\
\hline & 2 & 1 & 1 & 1 & 1 & 1 & 0 & 5 & \\
\hline
\end{tabular}

Negative Control=0.5-mL water topically, positive control=0.5-mL 10\% v/v povidone-iodine, Dose 1=0.5-mL 5\% v/v M. jalapa L. water extract, Dose 2=0.5-mL $10 \% \mathrm{v} / \mathrm{v}$ M. jalapa L. water extract, Dose 3=0.5-mL 20\% v/v M. jalapa L. water extract. Scoring: $1=$ exist qualitatively, $0=$ none. M. jalapa: Mirabilis jalapa

contraction parameters and histopathological indicators. An effective dose of $972.4 \mathrm{mg} / \mathrm{kg}$ body weight was determined.

\section{CONFLICTS OF INTEREST}

The authors declare that they have no conflicts of interest.

\section{REFERENCES}

1. Mansjoer A. Capita Selecta of Medicine. $3^{\text {rd }}$ ed. Jakarta: Media Aesculapius Faculty of Medicine, Universitas Indonesia; 2000.

2. Gunawan S. Pharmacology and Therapy. $5^{\text {th }}$ ed. Jakarta: FKUI; 2007.

3. Shaik S, Dhanalakshmi M, Jayasree T. Nephroprotective activity of leaves of Mirabilis jalapa. $\mathrm{L}$ by acetaminophen induced nephrotoxicity. Int J Pharm Technol 2012;4:4616-29.

4. Kumala S, Tambunan RM, Mochtar D. Anti-bacterial activity test of ethyl acetate extract at Mirabilis jalapa $\mathrm{L}$. With bioautography method. J Farmasi Indones 2006;3:78-83.

5. Hajji M, Jarrayab R, Lassoueda I, Masmoudia O, Damakb M, Nasria M. GC/MS and LC/MS analysis, and antioxidant and antimicrobial activities of various solvent extracts from Mirabilis jalapa tubers. Process Biochem 2010;45:1486-93.

6. Zachariah SM, Viswanad V, Aleykutty NA, Jaykar B, Halima OA. Free radical scavenging and antibacterial activity of Mirabilis jalapa Linn using in vitro models. Asian J Pharm Clin Res 2012;5:115-9.
7. Rumzhum NN, Rahman MM, Islam MS, Chowdhury SA, Sultana R, Pervin N. Cytotoxicity and antioxidant activity of extractives from Mirabilis jalapa. J Pharm Sci 2008;1:85-8.

8. Nath LR, Manjunath KP, Savadi RV, Akki KS. Anti-inflammatory activity of Mirabilis jalapa Linn. Leaves. J Basic Clin Pharm 2010;1:93-6.

9. Puratchikody A, Devi CN, Nagalakhsmi G. Wound healing activity of Cyperus rotundus Linn. Indian J Pharm Sci 2006;68:97-101.

10. Gogoi J, Nakhuru KS, Policegoudra RS, Chattopadhyay P, Rai AK, Veer V. Isolation and characterization of bioactive components from Mirabilis jalapa L. Radix. J Tradit Complement Med 2016;6:41-7.

11. Singh M, Akash G, Mittal SK, Kalia AN. Mirabilis jalapa - A review. Int J Pharm Med Appl Sci 2012;1:22-43.

12. Govindarajan P, Sarada DV. Isolation and chacterization of stigmasterol and $\beta$-sitosterol from Acacia nilotica (1.) Delile ssp Indica (benth.) Brenan. J Pharm Res 2011;4:3601-2.

13. Arroyo AR, Chacon BL, Maki KA. Screening and selection of plants by positive pharmacologic effect on jejenum muscular contractility. Pharm Biol 2005;42:24-9.

14. Oladunmoye MK. Antioxidant, free radical scavenging capacity and antimicrobial activities of Mirabilis jalapa. J Med Plants Res 2012;6:2909-13

15. Atiyeh BS, Al-Amm CA, Nasser AA. Improved healing of split thickness skin graft donor sites. J Appl Res 2000;2:78-85. 